Article

\title{
Farmers' Perception and Evaluation of Brachiaria Grass (Brachiaria spp.) Genotypes for Smallholder Cereal-Livestock Production in East Africa
}

\author{
Duncan Cheruiyot ${ }^{1,2, *}$, Charles A.O. Midega ${ }^{1}$, Jimmy O. Pittchar ${ }^{1}$, John A. Pickett ${ }^{3}(\mathbb{D}$ and \\ Zeyaur R. Khan ${ }^{1}$ \\ 1 International Centre of Insect Physiology and Ecology (icipe), P.O. Box 30772, Nairobi 00100, Kenya; \\ cmidega@icipe.org (C.A.M.); jpittchar@icipe.org (J.O.P.); zkhan@icipe.org (Z.R.K.) \\ 2 Department of Biological Sciences, Faculty of Science and Technology, University of Kabianga, P.O Box 2030, \\ Kericho 20200, Kenya \\ 3 School of Chemistry, Cardiff University, Cardiff CF10 3AT, UK; PickettJ4@cardiff.ac.uk \\ * Correspondence: duncan.cheruiyot@yahoo.com
}

Received: 27 May 2020; Accepted: 24 June 2020; Published: 4 July 2020

check for updates

\begin{abstract}
Brachiaria (Urochloa) is a genus, common name brachiaria, of forage grasses that is increasingly transforming integrated crop-livestock production systems in East Africa. A study was undertaken to (i) assess smallholder farmers' perception on benefits of brachiaria in cereal-livestock production, (ii) identify brachiaria production constraints, and (iii) identify farmer preferred brachiaria genotypes. A multi-stage sampling technique was adopted for sample selection. Data were collected through semi-structured individual questionnaire and focus group discussions (FGDs). The study areas included Bondo, Siaya, Homabay and Mbita sub-counties in Western Kenya and the Lake zone of Tanzania. A total of 223 farmers participated in individual response questionnaires while 80 farmers participated in the FGDs. The respondents considered brachiaria mainly important in management of cereal pests (70.4\% of respondents) and as an important fodder (60.8\%). The major production constraint perceived by both male and female respondents is attacks by arthropods pests $(49.2 \%$ and $63 \%$, respectively). Spider smites had been observed on own farms by $50.8 \%$ of men and $63.1 \%$ of women, while sorghum shoot flies had been observed by $58.1 \%$ of men and $67.9 \%$ of women. These pests were rated as a moderate to severe problem. Xaraes was the most preferred genotype, followed by Mulato II and Piata. These genotypes are important in developing new crop pest management strategies, such as push-pull, and for relatively rapid improvements in crop management and yield increases, particularly in developing countries.
\end{abstract}

Keywords: brachiaria; cereal-livestock production; perception; push-pull technology; smallholder farmers

\section{Introduction}

Brachiaria (Urochloa) is a genus in Poaceae family commonly called brachiaria and grown for forage in Latin America, Asia, South Pacific, and Australia [1]. A widely grown species Brachiaria brizantha represents $85 \%$ of cultivated pastures in brazil alone [2]. In Africa, where they originate from, they are natural constituents of grasslands in eastern, central, and southern regions [3]. Brachiaria is recently identified as an ideal fodder that can improve livestock production in eastern Africa. This is due to its adaptability to low fertility areas, arid, and semiarid zones of sub-Saharan Africa [3]. There are several initiatives in the region aimed at promoting cultivation of brachiaria to support the emerging livestock industry [4]. 
A reduction of fall armyworm, (Spodoptera frugiperda) damage was recently observed in push-pull technology (PPT) plots as compared to farmers' practice [5]. Furthermore, desmodium enhances soil integrity. Further, Brachiaria cv. Mulato II is an important companion crop used as a trap plant in a push-pull technology (PPT, www.push-pull.net). Developed by International Centre of Insect Physiology and Ecology (icipe, Nairobi, Kenya), Rothamsted Research (Harpenden, UK), and national partners, PPT is a conservation agriculture system for integrated pest, weed, and soil fertility management in crop-livestock farming systems [6,7]. The system involves intercropping the main crop, either maize Zea mays L. or sorghum Sorghum bicolor (L.) Moench with a fodder legume, silverleaf desmodium Desmodium uncinatum (Jacq.) DC., and surrounded with Napier grass, Pennisetum purpureum [8]. The climate smart variant uses drought tolerant green leaf desmodium, Desmodium intortum (Mill.) Urb., and brachiaria B. brizantha cv Mulato II as the border crop $[9,10]$. Desmodium releases chemicals that repel stemborers, while volatile chemicals from Napier grass or brachiaria attract the insects and their natural enemies. Through this chemistry, PPT significantly reduces the infestation of cereal stemborers Busseola fusca (Fuller) (Noctuidae) and Chilo partellus Swinhoe (Crambidae) [10-13]. Significant through nitrogen fixation improves soil organic content and conserves the soil moisture [14,15]. Root exudates of desmodium cause the abortive germination of a noxious weed striga Striga haemonthica, therefore providing additional benefits in weed management [11]. On the other hand, brachiaria is a high-value forage crop that facilitates milk production and diversifies farmers' sources of income. A recent study shows that B. brizantha cv Piata has higher content of dry matter, crude protein, and organic matter than Napier grass [16]. Some species of brachiaria reduce emission of nitrous oxide from the soil through biological nitrification inhibition [17,18].

Agriculture is an economic mainstay in most developing countries of the tropics. It is characterized by smallholder mixed crop-livestock systems where rain-fed crops and livestock are raised on the same farm [19]. In sub-Saharan Africa (SSA), smallholder farming is a major source of food production and income, contributing up to 80 percent of food consumed [20]. Crops mostly cultivated in the region are, in order, maize, cassava, rice, sorghum, wheat, and millet, while livestock species include cattle, goats, and sheep [19]. However, production in the region is constrained by climate change related biotic and abiotic constraints, including pests and disease outbreaks, extreme weather conditions, among others. This poses a threat to food security and livelihood in communities dependent on agriculture [21,22]. More than 250,000 smallholder farmers in sub-Saharan Africa have used push-pull technology to manage stemborers, fall armyworm, noxious Striga weeds, and soil fertility, and to generate livestock fodder [23].

The value of brachiaria to African agriculture observed thus far can be optimized by addressing the current and foreseeable production constraints. Yet, the few genotypes that are commercialized in Africa were developed for the Americas and Australia thus a higher risk of pest and disease attacks, coupled with poor adaptability to local environments. There is, remarkably, a wide genetic variation in the genus Brachiaria [24] that can be exploited in breeding programs for locally adapted genotypes. Recent studies identified brachiaria genotypes that combine drought tolerance and moderate resistance to spider mites $[25,26]$. Among these genotypes, some are attractive to oviposition by stemborer moths while being detrimental to the larvae of the pest, thus valuable in push-pull technology [27]. These genotypes could be of value in the improvement of cereal livestock-based livestock productivity in sub-Saharan Africa in the current scenarios of increasing aridification and attacks by invasive pests, such as spider mite (Oligonychus trichardti). However, farmers' skills and knowledge can complement scientific research and their contribution through participatory approach is key in validating the potential of such genetic materials. Therefore, this study aimed at (i) assessing smallholder farmers' perception on benefits of brachiaria in cereal-livestock production, (ii) assessing brachiaria production constrains, and (iii) identifying farmer preferred brachiaria genotypes.

\section{Materials and Methods}

\subsection{Study Area}

Arid and semi-arid areas of western Kenya and the lake zone in Tanzania were selected because of their importance in cereal-livestock based farming systems. The study areas in Kenya included 
Homabay, Mbita, Bondo, and Siaya. The lake zone in Tanzania (hereafter referred to Tanzania LZ) included Tarime and Mwanza districts. Rainfall pattern is bi-modal, main season runs from March to August and the short season is from October to January. Farming systems in the regions are predominantly cereal/edible legume integrated with livestock [6]. These areas are historically hot spots for cereal stemborer, and most farmers have widely adopted push-pull technology (PPT) as a management tool for the pest [5]. Further, the areas are characterized by extended periods of drought, which makes them conducive for the invasive spider mite, O. trichardti. Spider mite is the most important pest of brachiaria, a companion crop in PPT, especially during drier and hotter regimes [26]. These study areas are therefore ideal for assessment of farmers' experience and preference of brachiaria genotypes for use in cereal-livestock production.

\subsection{Demonstration Plots}

One site per study area was selected for the establishment of the demonstration plots for six brachiaria genotypes. This was purposely done by ensuring that they occur in different agro-ecologies, as follows; Homabay (Lower Midland 3), Mbita (Lower midland 5), Bondo (Lower midland 4), and Siaya (Lower midland 2) [28]. The lake zone sites in Tanzania included Tarime (high altitude plateau) and Mwanza (medium altitude plains) [29]. Brachiaria genotypes that were planted for evaluation were Piata, Xaraes, Marandu, ILRI 12991, ILRI 14807, and Mulato II (check). The candidate genotypes were selected from previous studies that tested drought tolerance, adaptability to a range of environments, and resistance to spider mite in brachiaria $[25,26]$. Furthermore, Xaraes, Piata, and Marandu are suitable for egg laying by the lepidopterous stemborer Chilo partellus and are, therefore, suitable companion plants in PPT [27]. Each plot measured $5 \times 5 \mathrm{~m}$ with plant to plant and row to row spacing of $0.5 \mathrm{~m}$. Diammonium phosphate (DAP) was applied as basal fertilizer at a rate of $60 \mathrm{~kg} / \mathrm{ha}$, and nitrogen in the form of calcium ammonium nitrate (CAN), at a rate of $60 \mathrm{~kg} / \mathrm{ha}$ as at top dresser four weeks after planting. The plots were kept weed free by hoe and hand weeding and pesticides were not applied to allow natural infestation and the development of spider mites.

\subsection{Sampling Procedures}

The selection of respondents to participate in study at specific trial sites followed a multistage sampling procedure. Firstly, farmers who practiced climate smart PPT and were within the study areas were selected for the study. This was done by generating a checklist of all farmers who practice climate smart PPT with help of village elders and frontline extension staff. Thereafter, a semi-structured questionnaire was used to identify willing respondents for participatory evaluation of different brachiaria genotypes grown in the demonstration plots.

\subsection{Data Collection}

The study used semi-structured questionnaires that were administered through individual interviews and focus group discussions (FGD). The questionnaires were pre-tested before implementation. Individual response questionnaire assessed farmers' socio-economic characteristics (e.g., age, gender, and education), farm characteristics (farm size, tenure system, size of land under brachiaria, and uses of brachiaria). Farmers' perceptions on whether brachiaria was beneficially in controlling cereal pests, for sale, as livestock feed, for soil conservation, etc., was sought. Production challenges, including access to planting materials, planting, crop management, harvesting, and hay making was recorded. The questionnaire also assessed farmer experience with pests and diseases of brachiaria. This was captured by asking the respondents whether they had noticed the infestation of the red spider mites and sorghum shoot flies; severity of infestation; and, what they did to cope with the pests. Rating of the seriousness of the pest was based on a four-point Likert scale, where $0=$ no problem, $1=$ moderate problem, 2 = severe problem, and $3=$ very severe problem. Farmers were asked whether they are aware of any other brachiaria genotypes and whether they had planted them on their farms. Thereafter, farmers evaluated the different brachiaria genotypes in demonstration based on hairlines, leaf size, leaf softness, number of shoot tillers, plant spread, plant height, seed setting, resistance to spider 
mites, and biomass yield where their responses were based on a scale of 1 (poor), 2 (fair), 3 (good), and 4 (excellent). However, for each trait, the number of the highest score i.e., 4 (excellent) was used to compare the genotypes. Evaluation based on sorghum shoot fly damage was not done, since there was no infestation; this is because the genotypes were raised from root splits. Sorghum shoot flies are known to attack young seedlings, especially when grown from the seed. During the assessment, the genotypes were given numbers instead of their actual names to reduce bias in ranking of popular genotypes. Farmers were finally asked to select the best brachiaria genotype. To back up individual interviews, focus group discussions were conducted. Farmers were encouraged to use a language that they were most familiar with and discussions were led by a member of the research group who spoke their language. Similarly, the discussions covered the benefits of brachiaria in climate smart PPT, production constraints, including important pests (spider mites and sorghum shoot flies), and farmer preference of different brachiaria genotypes. Other aspects that were covered in the FGD included willingness of the farmers to try other brachiaria genotypes on their farms and the criteria used for selecting a candidate genotype.

\subsection{Data Analysis}

Descriptive and comparative statistics (means, percentages, and cross tabulations) were used in data analysis. Analysis of variance, F-test, and Pearson's product moment correlation coefficient (chi-square test) were used to test for significance of differences in various responses and study areas. Computation was done using statistical package for SPSS version 17 software (IBM Corporation, Armonk, NY, USA).

\section{Results}

\subsection{Farmer Socio-demographics and Farm Characteristics}

A total of 223 respondents participated in individual interviews. In general, $49 \%$ of the respondents are male. There was no significance $(p=0.05)$ in variation between districts (Table 1$)$. Their age categories varied significantly $(p=0.01)$ between the study areas. The majority were between $41-50$ years (31\%), followed by 51-60 years (22\%), the elderly $>61(19 \%), 31-40(15 \%)$, and the least being the youth between 20-30 years (8\%). Age category 41-50 years formed the highest percentage in all study areas, except in Siaya, where the majority were between 51-60. The lowest in population in all areas were the youth (20-30 years), implying that farming in the region is predominantly practiced by the older and the elderly farmers. Education levels of the respondents varied significantly across the study areas. On average, $50 \%$ of the farmers had attained primary education, $31 \%$ had secondary education, a few $(9 \%)$ had post-secondary education, while those with none-formal and no education at all were the least, each comprising of $4 \%$ of the respondents. Literacy at post-secondary level was the highest in Bondo (15\%), while illiteracy (no education) was highest in Siaya (13\%) (Table 1).

Farmers rented an average of 1.5 acres land for farming. This varied significantly across the study areas ranging from one acre (Homabay) to two acres (Mbita). The average farm size owned was 3.5 acres, and it varied significantly ( $p=0.01$ ) from two acres (Siaya) to 5.2 (Homabay). The average land size under brachiaria as components of push-pull was 0.17 acres, this however did not vary significantly across the study areas (Table 1). Besides the brachiaria that forms a component of push-pull, $22 \%$ of farmers planted the grass as pure stands; $32 \%$ in Homabay, $3 \%$ in Mbita, $19 \%$ in Bondo, 39\% in Siaya, and $11 \%$ in Tanzania. The majority of the farmers (93\%) kept livestock that included cattle (improved and local), goats (improved and local), and sheep. The type of livestock mostly kept was local cattle with a mean of 2.9, followed by local goats (1.94), sheep (1.65), improved dairy cattle (0.72), and improved dairy goats (0.56). Variation across study areas was not significant for all animals, except sheep $(p=0.01)$. The highest number of sheep was recorded in Homabay (2.92), while the lowest was in Siaya (0.64). 
Table 1. Socio-economic characteristics of the respondents.

\begin{tabular}{|c|c|c|c|c|c|c|c|c|}
\hline & Homabay & Mbita & Bondo & Siaya & Tanzania & Mean & & \\
\hline Variable & $(n=38)$ & $(n=38)$ & $(n=67)$ & $(n=54)$ & $(n=26)$ & $(n=45)$ & F Value & $x^{2}$ value \\
\hline Gender (male) (\%) & 53 & 45 & 46 & 37 & 62 & 48.6 & & \\
\hline Age category $(\%)$ & & & & & & & & $32.842 * *$ \\
\hline $20-30$ & 18 & 8 & 3 & 6 & 4 & 7.8 & & \\
\hline $31-40$ & 13 & 24 & 16 & 15 & 8 & 15.2 & & \\
\hline $41-50$ & 24 & 37 & 30 & 24 & 42 & 31.4 & & \\
\hline $51-60$ & 18 & 13 & 21 & 31 & 27 & 22 & & \\
\hline \multirow{2}{*}{$>61$} & 13 & 16 & 28 & 22 & 16 & 19 & & \\
\hline & 86 & 98 & 98 & 98 & 97 & 95.4 & & \\
\hline Education level (\%) & & & & & & & & $26.515 *$ \\
\hline None & 3 & 0 & 5 & 13 & 0 & 4.2 & & \\
\hline None-formal & 3 & 8 & 4 & 2 & 4 & 4.2 & & \\
\hline Primary & 50 & 42 & 43 & 50 & 69 & 50.8 & & \\
\hline Secondary & 34 & 42 & 34 & 20 & 27 & 31.4 & & \\
\hline Post-Secondary & 8 & 8 & 15 & 13 & 0 & 8.8 & & \\
\hline Average land size rented (acres) & 1.08 & 2.05 & 1.63 & 0.92 & 2 & & $2.856^{*}$ & \\
\hline Land size owned (acres) & 5.29 & 2.8 & 2.67 & 2.05 & 4.74 & & $4.59 * *$ & \\
\hline Size of brachiaria plots in push pull $\left(\mathrm{m}^{2}\right)$ & 793 & 634 & 655 & 603 & 734 & 670 & $0.329 \mathrm{~ns}$ & \\
\hline Brachiaria grown as pure stands & 32 & 3 & 19 & 39 & 11 & 22.5 & & $21.159^{* * *}$ \\
\hline Keeping of livestock on farm & 95 & 100 & 84 & 94 & 100 & 93 & & $13.963 * *$ \\
\hline Improved dairy cattle & 0.42 & 0.97 & 0.49 & 0.79 & 1.23 & 0.72 & $1.738 \mathrm{~ns}$ & \\
\hline Local cattle & 3.42 & 3.37 & 2.46 & 2.51 & 3.65 & 2.9 & $1.727 \mathrm{~ns}$ & \\
\hline Improved dairy goats & 0.86 & 0.53 & 0.63 & 0.57 & 0 & 0.56 & $1.841 \mathrm{~ns}$ & \\
\hline Local goats & 1.92 & 2.02 & 2.08 & 1.05 & 3.3 & 1.94 & $2.15 \mathrm{~ns}$ & \\
\hline Sheep & 2.92 & 2.68 & 1.4 & 0.64 & 1.65 & 1.74 & $4.395^{* *}$ & \\
\hline
\end{tabular}

${ }^{*}=$ significant at $0.05,{ }^{* *}=$ significant at $0.01, * * *=$ significant at $0.001, \mathrm{~ns}=$ not significant. 


\subsection{Benefits of Brachiaria}

The uses of brachiaria varied significantly across the study areas, except for those who exchanged the grass for milk (mean $=5 \%$ ). Being a component of a pest management strategy, approximately $38 \%$ (mean) of farmers agreed that brachiaria reduced damage caused by cereal pests (Figure 1). Approximately $36 \%$ of the farmers considered the grass as a valuable fodder for livestock. About $29 \%$ believed that it controls soil erosion, while a few $(17 \%)$ also sold the grass, others exchanged it for milk (Figure 1).

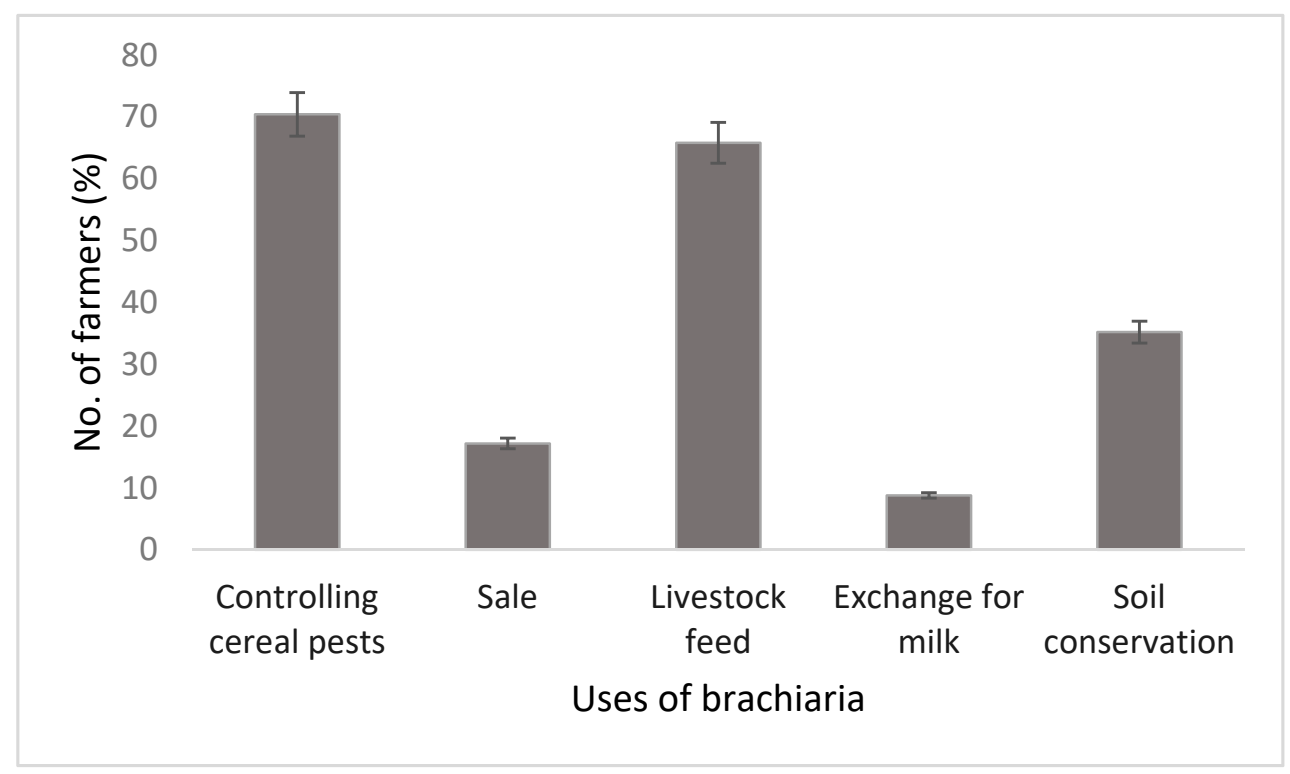

Figure 1. Main uses of brachiaria by the small-holder push pull farmers.

\subsection{Constraints to Production of Brachiaria}

Farmers gave their opinions on challenges faced in accessing planting materials, during planting and management (Table 2). The opinions varied across the study sites. The major production constraint perceived by both men and women was attacks by arthropod pests (49.2\% and 63.1, respectively). This was followed by disease infestation ( $44.4 \%$ of men and $30.6 \%$ of women). The difficulty in handling (prickly hairs) was rated as the third constraint by women $(24.7 \%)$ while unavailability of seed in agrovets was rated third by men $(16 \%)$. However, farmers were specific about the most important arthropod pests. Spider smites were reported to have been observed on own farms by $50.8 \%$ of men and $63.1 \%$ of women, while sorghum shoot flies had been observed by $58.1 \%$ of men and $67.9 \%$ of women. The seriousness of spider mites was mostly perceived by both men and women as moderate problem (63.4\% and $44.7 \%$, respectively) to severe problem ( $21 \%$ and $33.9 \%$, respectively). Sorghum shoot flies were also regarded by both men and women as a moderate problem $(58.8 \%$ and $52.2 \%$, respectively) to severe problem ( $15.8 \%$ and $22.4 \%$, respectively). Further, more farmers $(55.6 \%$ men and $63.2 \%$ women) had observed spider mites on other farms. On the other hand, more men $(50.3 \%)$ had not observed sorghum shoot flies on other farms, while more women $(53.1 \%)$ have observed. 
Table 2. Perception on brachiaria production challenges disaggregated by gender.

\begin{tabular}{|c|c|c|c|c|c|c|c|c|c|c|c|c|c|}
\hline \multirow{2}{*}{ Variable } & \multirow{2}{*}{ Response/Rating (\%) } & \multicolumn{2}{|c|}{ Homabay $(n=38)$} & \multicolumn{2}{|c|}{ Mbita $(n=38)$} & \multicolumn{2}{|c|}{ Bondo $(n=67)$} & \multicolumn{2}{|c|}{ Siaya $(n=54)$} & \multicolumn{2}{|c|}{ Tanzania $(n=26)$} & \multicolumn{2}{|c|}{ Mean $(n=45)$} \\
\hline & & Male & Female & Male & Female & Male & Female & Male & Female & Male & Female & Male & Female \\
\hline \multirow{3}{*}{$\begin{array}{l}\text { Access to planting } \\
\text { materials }\end{array}$} & Do not know where to get seeds & 5 & 0 & 11.8 & 23.8 & 22.6 & 13.9 & 0 & 0 & 6.3 & 0 & 9.1 & 7.5 \\
\hline & Planting materials are expensive & 15 & 0 & 0 & 0 & 0 & 2.8 & 20 & 5.9 & 0 & 0 & 7 & 1.7 \\
\hline & Unavailability of seeds in Agrovets & 30 & 33.3 & 0 & 0 & 0 & 2.8 & 25 & 23.5 & 25 & 0 & 16 & 11.9 \\
\hline \multirow{3}{*}{ Planting } & Time consuming & 0 & 5.6 & 0 & 0 & 3.2 & 0 & 10 & 8.8 & 6.3 & 0 & 3.9 & 2.9 \\
\hline & Do not know planting procedure & 0 & 0 & 5.9 & 0 & 3.2 & 8.3 & 0 & 0 & 0 & 0 & 1.8 & 1.7 \\
\hline & Poor germination of seeds & 0 & 5.6 & 5.9 & 0 & 0 & 0 & 5 & 5.9 & 37.5 & 20 & 9.7 & 6.3 \\
\hline \multirow{2}{*}{ Crop management } & Difficulty in controlling weeds & 15 & 11.1 & 11.8 & 4.8 & 3.2 & 0 & 10 & 23.5 & 0 & 0 & 8 & 7.9 \\
\hline & Difficulty in handling (it pricks) & 5 & 5.6 & 29.4 & 57.1 & 0 & 2.8 & 20 & 38.2 & 12.5 & 20 & 13.4 & 24.7 \\
\hline \multirow{2}{*}{$\begin{array}{l}\text { Arthropod pest } \\
\text { attacks }\end{array}$} & Yes & 50 & 66.7 & 75 & 60 & 68.4 & 77.8 & 27.8 & 31.3 & 25 & 80 & 49.2 & 63.1 \\
\hline & No & 50 & 33.3 & 25 & 40 & 31.6 & 22.2 & 72.2 & 68.8 & 75 & 20 & 50.8 & 36.9 \\
\hline Spider mites & Yes & 58 & 66.7 & 75 & 60 & 68.4 & 77.8 & 27.8 & 31.3 & 25 & 80 & 50.8 & 63.1 \\
\hline \multirow[t]{2}{*}{ on own farm } & No & 42 & 33.3 & 25 & 40 & 31.6 & 22.2 & 72.2 & 68.8 & 75 & 20 & 49.2 & 36.9 \\
\hline & No problem & 18.2 & 11.1 & 12.5 & 18.8 & 5.3 & 4.5 & 12.5 & 46.7 & 0 & 0 & 9.7 & 16.2 \\
\hline \multirow{3}{*}{$\begin{array}{l}\text { Seriousness of mites } \\
\text { on own farms }\end{array}$} & Moderate problem & 45.5 & 22.2 & 37.5 & 37.5 & 78.9 & 54.5 & 75 & 46.7 & 80 & 62.5 & 63.4 & 44.7 \\
\hline & Severe problem & 18.2 & 66.7 & 43.8 & 31.3 & 10.5 & 27.3 & 12.5 & 6.7 & 20 & 37.5 & 21 & 33.9 \\
\hline & Very severe problem & 9.1 & 0 & 6.3 & 12.5 & 5.3 & 13.6 & 0 & 0 & 0 & 0 & 4.1 & 5.2 \\
\hline \multirow{5}{*}{$\begin{array}{l}\text { Spider mites seen on } \\
\text { other farms } \\
\text { Seen shoot flies on } \\
\text { own farm }\end{array}$} & Yes & 46.7 & 57.1 & 68.8 & 52.9 & 94.7 & 91.7 & 27.8 & 34.5 & 40 & 80 & 55.6 & 63.2 \\
\hline & No & 53.3 & 42.9 & 31.3 & 47.1 & 5.3 & 8.3 & 72.2 & 65.5 & 60 & 20 & 44.4 & 36.8 \\
\hline & Yes & 57.1 & 66.7 & 81.3 & 61.9 & 93.3 & 100 & 5.6 & 21.9 & 53.3 & 88.9 & 58.1 & 67.9 \\
\hline & No & 42.9 & 33.3 & 18.8 & 38.1 & 6.7 & 0 & 94.4 & 78.1 & 46.7 & 11.1 & 41.9 & 32.1 \\
\hline & No problem & 20 & 7.7 & 13.3 & 20 & 6.7 & 0 & 60 & 46.2 & 0 & 0 & 20 & 14.8 \\
\hline \multirow{3}{*}{$\begin{array}{l}\text { Seriousness of } \\
\text { shoot flies }\end{array}$} & Moderate problem & 60 & 46.2 & 33.3 & 33.3 & 73.3 & 60 & 40 & 53.8 & 87.5 & 77.8 & 58.8 & 54.2 \\
\hline & Severe problem & 20 & 30.8 & 26.7 & 40 & 20 & 30 & 0 & 0 & 12.5 & 11.1 & 15.8 & 22.4 \\
\hline & Very severe problem & 0 & 15.4 & 26.7 & 6.7 & 0 & 10 & 0 & 0 & 0 & 11.1 & 5.3 & 8.6 \\
\hline \multirow{2}{*}{$\begin{array}{l}\text { Seen shoot flies on } \\
\text { other farms }\end{array}$} & Yes & 50 & 62.5 & 76.5 & 55.6 & 93.3 & 100 & 10 & 3.1 & 18.8 & 44.4 & 49.7 & 53.1 \\
\hline & No & 50 & 37.5 & 23.5 & 44.4 & 6.7 & 0 & 90 & 93.8 & 81.3 & 55.6 & 50.3 & 46.3 \\
\hline \multirow[t]{2}{*}{ Disease infestation } & Yes & 26.7 & 26.7 & 64.7 & 28.6 & 90.9 & 81.3 & 21.1 & 16.7 & 18.8 & 0 & 44.4 & 30.6 \\
\hline & No & 73.3 & 73.3 & 35.3 & 71.4 & 9.1 & 18.8 & 78.9 & 83.3 & 81.3 & 100 & 55.6 & 69.4 \\
\hline
\end{tabular}




\subsection{Farmer Evaluation and Selection of Brachiaria Genotypes}

Farmers assessed the six brachiaria genotypes based on the following criteria; leaf hairlines, leaf size, leaf softness, number of shoot tillers, plant spread, plant height, seed setting, resistance to the spider mites, and visual estimation of biomass yield. Mulato II ranked the highest in hairlines, leaf softness, and tillers, while Xaraes had the highest numbers for plant height, resistance to spider mites, and biomass yield (Figure 2). Sorghum shoot flies attack the crop at the seedling stage, especially when seed is used as a propagation material. Due to unavailability seeds, we used root splits in our study, further, the crop was evaluated at maturity. Therefore, farmers could not evaluate the materials based on resistance to Sorghum shoot flies. Figure 3 presents the farmer selection of different brachiaria genotypes. Generally, the majority $(41.2 \%)$ of the farmers preferred Xaraes, followed by Mulato II (25.6\%) and Piata (20.4\%).

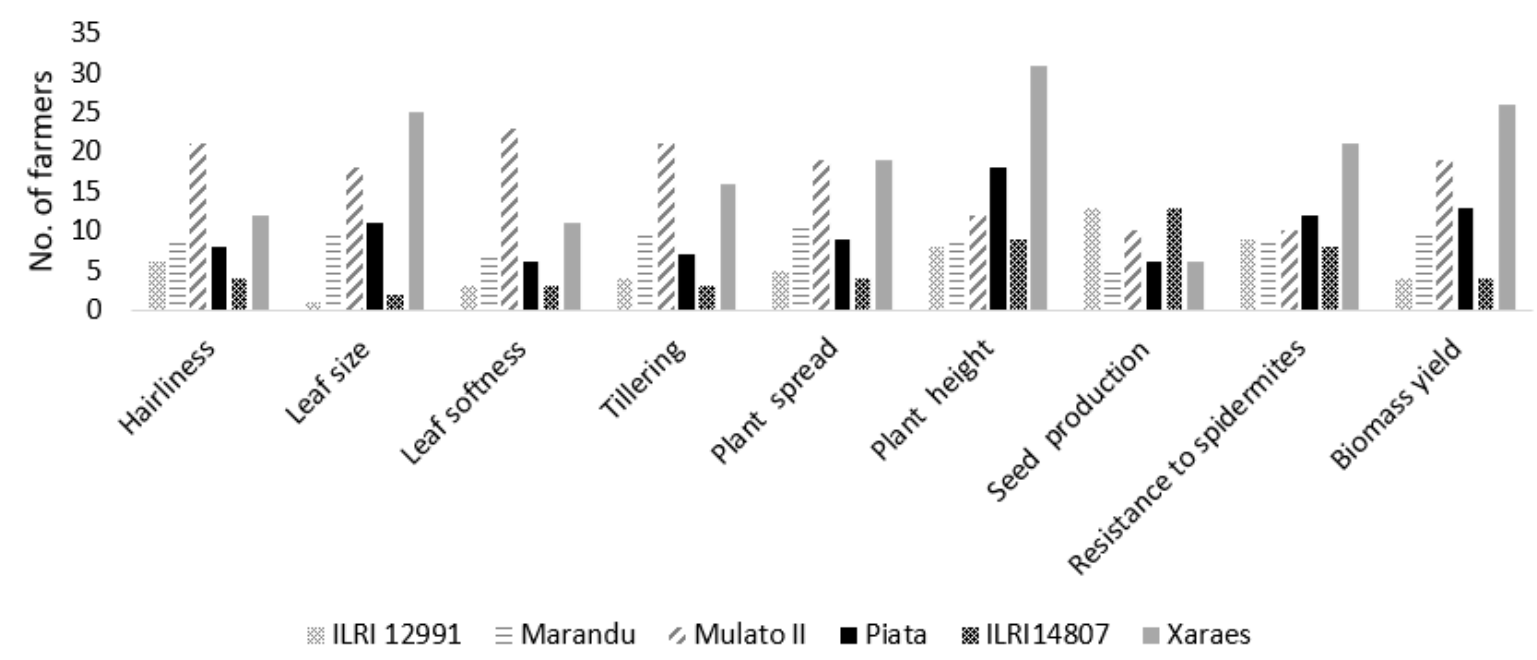

Figure 2. Average number of farmers recorded for the highest score 4 (excellence) for different traits of brachiaria.

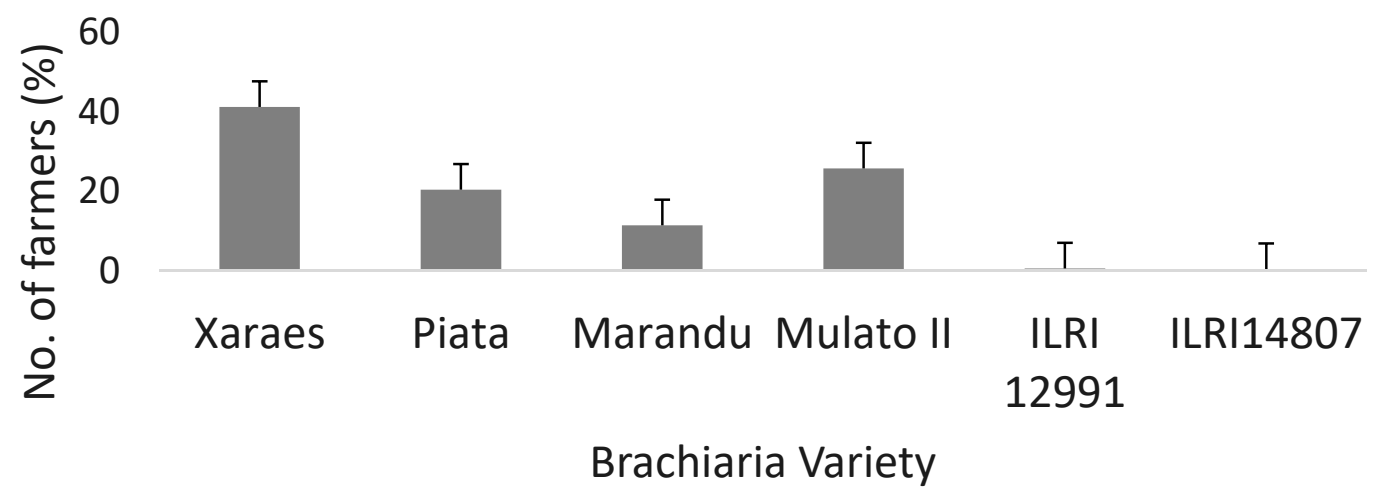

Figure 3. Means for number of farmers (\%) for each brachiaria genotype across all the districts. Bars represent standard error of the means.

\section{Discussion}

The study assessed farmers' experiences and perceptions of brachiaria, a companion crop in a climate-smart PPT. To date, Brachiaria brizantha cv. Mulato II is the only variety planted by PPT farmer; therefore, farmers' experience with brachiaria in PPT, as assessed in this study, is based on this variety. However, some farmers may have planted a different variety, but in pure crop stands. The respondents comprised a slightly higher number of females than males. This shows that women are significant and crucial in agricultural development in the region. Studies have shown that, even though most of the African cultures discriminate against women, limiting their land and property rights, they still 
account for nearly half of the smallholder farmers [30]. Respondents in the study fall in different age categories with the majority being adults between 41-50, while the lowest comprises of the youth between 20-30 years. There is an emerging debate regarding the declining interest of Africa's young people in agriculture [31]; this trend is evident in the current study. Youth can play a key role in agriculture. Unlike the older people, they have greater energy and education and are better equipped to handle modern agricultural technologies and entrepreneurship and they can reverse the ageing trend of the African farming population. It is perhaps worth mentioning that there is a greater interest in sustainability, e.g., of PPT, by those in lower age groups and that this might also improve gender parity in agriculture. One of the major challenges that the young prospective farmers experience is a lack of access to assets and resources that would increase their productivity, such as land, farming inputs, and tools [32]. However, PPT can solve some resource related problems, as all companion crops are perennial and self-saved cereal seed performs better in PPT than do most commercial hybrids [32].

The study provides evidence that brachiaria is an important source of fodder besides its prominent use in pest management strategy (Figure 1). It is used as "pull" component for cereal pests in the climate adapted push-pull technology (PPT); a habitat management strategy that was initially developed to manage the lepidopterous stemborers [7]. In a recent farmer perception study, farmers rated the climate-adapted push-pull as being superior in reducing fall armyworm damage on maize [5]. There is shortage of forages in quantity and quality in sub-Saharan Africa, especially during the dry seasons [33]; therefore, the study validates the value of brachiaria as an ideal forage in the region. Other uses of brachiaria, as mentioned by the farmers, include soil conservation by the prevention of soil erosion, sale, and exchange for milk (Figure 1). Brachiaria grasses are well known for improving soil aggregation thus increasing the resistance to soil degradation and erosion [34]. However, farmers listed several production challenges mainly being unavailability of brachiaria seeds in local retail agents, followed by weed and pest attacks and poor seed germination among others (Table 2). The unavailability of seed is mainly caused by high import costs, cumbersome seed registration processes, relatively undeveloped forage seed market, physical constraints, like drought, low germination rates, and the perceived high opportunity cost of growing the seed in Africa. Furthermore, local brachiaria seed production is underdeveloped, partly due reluctance by the private sector citing unorganized and dispersed demand for seed [35].

Arthropod pests are among the major causes of chronic food insecurity witnessed in the region and are expected to worsen with increasing hot and dry conditions associated with climate change [36]. Strategies to minimize such constrains are crucial in the intensification of smallholder farming systems towards achieving food security in the region. Farmers cited spider mites and sorghum shoot flies as main production challenges and as the main pests of Brachiaria brizantha cv. Mulato II. They mostly rated both pests as moderate to severe problem. Susceptibility of Mulato II to spider mites has been reported in previous studies [26]. Common symptoms of pest damage on brachiaria, as described by respondents in a focus group discussion (FGD), include: stunted growth, yellowing of leaves, and wilting of growing tips. Spider mites are tiny and difficult to detect; they are manifested through yellowing of leaves, which the farmers often confuse for mineral deficiency.

Nevertheless, crop improvement based on conventional breeding will continue to be important; many cycles of crossing and backcrossing (pre-breeding) are required to detect and map useful traits [37]. Brachiaria genotypes developed in the Americas and Australia have a higher risk of pest and disease attacks as well as poor adaptability in new environments in Africa. This kind of research involving farmers helps to generate and validate new strategies of integrating crop protection and livestock production which are locally adaptable, and can be introduced widely and applied more rapidly through the discovery of unique traits of companion plants. The introduction of pest-resilient trap plants in push-pull ensures that the technology's full range of opportunities for yield enhancement are exploited in Africa. 
When considering the susceptibility of Mulato II to spider mites, there is a need to deploy alternative resistant genotypes, which possess same properties that make them preferred for egg laying by stemborer moths. However, for the successful uptake of such materials, farmers' needs and opinions are key. Farmers evaluated and selected their preferred genotypes from candidate varieties proposed from previous studies, which evaluated drought tolerance, resistance to spider mites, biomass yield, and attractiveness to oviposition by stemborers [25-27]. Xaraes was a highly preferred genotype, followed by Mulato II and Piata (Figure 3). Some of the traits that farmers proposed as a criteria in evaluating brachiaria genotypes are leaf hairlines, leaf size, leaf softness (as a measure of palatability by animals), number of tillers, plant spread, plant height, seed production, resistance to spider mites, and biomass yield. Farmers generally prefer less hairy genotypes for ease in cut and carry, because the hairs are irritating to the skin. They also believe that softer leaves are highly palatable and preferred by the animals, a trait for which they voted Mulato II as superior. However, there is a trade-off between hairlines and leaf softness in Mulato II and this might produce mixed results in farmers' rating of the cultivar.

The results of this study are important to policy makers in sub-Saharan Africa because the sustainable increase in agricultural productivity represents a significant opportunity for addressing the pervasive challenge of low productivity, which results in high poverty levels and under-nourishment. Moreover, climate-smart and resilient agricultural systems that are based on such genetic material are needed to protect and enhance natural resources and ecosystem services in ways that mitigate future climate change [38]. The exploitation of such climate-smart, resilient material help farmers to develop production systems that are compatible with their farming systems, and sound management of available natural resources. The involvement of farmers in scientific developments in agronomy and agroecological practices take into account their other on-farm enterprises, like livestock keeping, and helps them to fully exploit the benefits of production and resource conservation technologies.

\section{Conclusions}

The study provides evidence that brachiaria is an important source of fodder besides its prominent use in pest management strategy. Its multiple utility facilitates sustainable intensification of smallholder agriculture by facilitating the integration of cereal and livestock fodder production. It is used as "pull" component for cereal pests in the climate adapted push-pull technology (PPT), a habitat management strategy initially developed to manage the lepidopterous stemborers, while it generated quality fodder. The study demonstrates that these Brachiaria genotypes could be of value in the improvement of cereal livestock-based livestock productivity in sub-Saharan Africa in the current scenarios of increasing aridification and attacks by invasive pests, such as spider mite (Oligonychus trichardti). It also demonstrates that farmers' skills and knowledge can complement scientific research, and that their contribution through participatory approach is key in validating the potential of such genetic materials.

Author Contributions: Conceptualization, D.C., C.A.M., J.A.P. and Z.R.K.; Formal analysis, J.O.P.; Funding acquisition, C.A.M., J.A.P. and Z.R.K.; Investigation, D.C. and J.O.P.; Methodology, D.C., J.O.P., J.A.P. and Z.R.K.; Project administration, C.A.M. and Z.R.K.; Resources, C.A.M., J.O.P., J.A.P. and Z.R.K.; Supervision, C.A.M. and Z.R.K.; Validation, C.A.M.; Writing—original draft, D.C.; Writing—review \& editing, D.C., J.O.P. and J.A.P. All authors have read and agreed to the published version of the manuscript.

Funding: We gratefully acknowledge the financial support for this research by the following organizations and agencies: European Union; Biovision foundation; UK's Department for International Development (DFID); Swedish International Development Cooperation Agency (Sida); the Swiss Agency for Development and Cooperation (SDC); Norwegian Agency for Development Cooperation (NORAD) and the Ethiopian and Kenyan Governments. The views herein do not necessarily reflect the official opinion of the donors.

Acknowledgments: We further thank the International Centre for Tropical Agriculture (CIAT) and International Livestock Research Institute (ILRI) for provision of brachiaria genotypes studied. The authors also acknowledge contributions by the farmers, icipe field staff, Kenyan Ministry of Agriculture extension staff and Tanzania Agricultural Research Institute staff.

Conflicts of Interest: The authors declare no conflict of interest. 


\section{References}

1. Miles, J.W.; Do Valle, C.B.; Rao, I.M.; Euclides, V.P.B. Brachiariagrasses. In Warm-Season $\left(C_{4}\right)$ Grasses; Moser, L.E., Burson, B.L., Sollenberger, L.E., Eds.; Agronomy Monographs; American Society of Agronomy, Crop Science Society of America, Soil Science Society of America: Madison, WI, USA, 2004; Volume 45, pp. 745-783.

2. Jank, L.; Alves, G. The value of improved pastures to Brazilian beef production. Crop Pasture Sci. 2014, 65, 1132-1137. [CrossRef]

3. Boonman, G. East Africa's Grasses and Fodders: Their Ecology and Husbandry; Springer: Heidelberg, Germany, 1993.

4. Maass, B.L.; Midega, C.A.O.; Mutimura, M.; Rahetlah, V.B.; Salgado, P.; Kabirizi, J.M.; Khan, Z.R.; Ghimire, S.R.; Rao, I.M. Homecoming of Brachiaria: Improved hybrids prove useful for African animal agriculture. East Afr. Agric. For. J. 2015, 81, 71-78. [CrossRef]

5. Midega, C.A.O.; Pittchar, J.O.; Pickett, J.A.; Hailu, G.W.; Khan, Z.R. A climate-adapted push-pull system effectively controls fall armyworm, Spodoptera frugiperda (J E Smith), in maize in East Africa. Crop Prot. 2018, 105, 10-15. [CrossRef]

6. Khan, Z.R.; James, D.G.; Midega, C.A.O.; Pickett, J.A. Chemical ecology and conservation biological control. Biol. Control. 2008, 45, 210-224. [CrossRef]

7. Khan, Z.; Midega, C.; Pittchar, J.; Pickett, J.; Bruce, T. Push-pull technology: A conservation agriculture approach for integrated management of insect pests, weeds and soil health in Africa. Int. J. Agric. Sustain. 2011, 9, 162-170. [CrossRef]

8. Khan, Z.; Midega, C.A.O.; Hooper, A.; Pickett, J. Push-Pull: Chemical Ecology-Based Integrated Pest Management Technology. J. Chem. Ecol. 2016, 42, 689-697. [CrossRef]

9. Khan, Z.R.; Midega, C.A.O.; Pittchar, J.; Bruce, T.J.A.; Pickett, J.A. 'Push-pull' revisited: The process of successful deployment of a chemical ecology-based pest management tool. In Biodiversity and Insect Pests: Key Issues for Sustainable Management; Gurr, G.M., Wratten, S.D., Snyder, W.E., Read, D.M.Y., Eds.; John Wiley \& Sons Ltd.: Hoboken, NJ, USA, 2012; pp. 259-275.

10. Pickett, J.A.; Woodcock, C.M.; Midega, C.A.O.; Khan, Z.R. Push-pull farming systems. Curr. Opin. Biotechnol. 2014, 26, 125-132. [CrossRef]

11. Khan, Z.R.; Pickett, J.A.; Wadhams, L.; Muyekho, F. Habitat management strategies for the control of cereal stemborers and striga in maize in Kenya. Int. J. Trop. Insect Sci. 2001, 21, 375-380. [CrossRef]

12. Khan, Z.R.; Midega, C.A.O.; Bruce, T.J.A.; Hooper, A.M.; Pickett, J.A. Exploiting phytochemicals for developing a 'push-pull' crop protection strategy for cereal farmers in Africa. J. Exp. Bot. 2010, 61, 4185-4196. [CrossRef]

13. Pickett, J.A.; Khan, Z.R. Plant volatile-mediated signaling and its application in agriculture: Successes and challenges. New Phytol. 2016, 212, 856-870. [CrossRef]

14. Khan, Z.; Hassanali, A.; Pickett, J. Managing polycropping to enhance soil system productivity: A case study from Africa. In Biological Approaches to Sustainable Soil Systems; Ball, A.S., Thies, J., Sanginga, N., Sanchez, P., Pretty, J., Palm, C., Laing, M., Herren, H., Fernandes, E., Uphoff, N., Eds.; CRC Press: Boca Raton, FL, USA, 2006; pp. 575-586.

15. Midega, C.A.O.; Wasonga, C.J.; Hooper, A.M.; Pickett, J.A.; Khan, Z.R. Drought-tolerant Desmodium species effectively suppress parasitic striga weed and improve cereal grain yields in western Kenya. Crop Prot. 2017, 98, 94-101. [CrossRef] [PubMed]

16. Mutimura, M.; Ebong, C.; Rao, I.M.; Nsahlai, I.V. Effects of supplementation of Brachiaria brizantha cultivar Piatá and Napier grass with Desmodium distortum on feed intake, digesta kinetics and milk production by crossbred dairy cows. Animal Nutr. 2018, 4, 222-227. [CrossRef] [PubMed]

17. Subbarao, G.V.; Nakahara, K.; Hurtado, M.P.; Ono, H.; Moreta, D.E.; Salcedo, A.F.; Yoshihashi, A.T.; Ishikawa, T.; Ishitani, M.; Ohnishi-Kameyama, M.; et al. Evidence for biological nitrification inhibition in Brachiaria pastures. Proc. Natl. Acad. Sci. USA 2009, 106, 17302-17307. [CrossRef] [PubMed] 
18. Moreta, D.E.; Arango, J.; Sotelo, M.; Vergara, D.; Rincón, A.; Ishitani, M.; Castro, A.; Miles, J.; Peters, M.; Tohme, J.O.E.; et al. Biological nitrification inhibition (BNI) in Brachiaria pastures: A novel strategy to improve eco-efficiency of crop-livestock systems and to mitigate climate change. Trop. Grassl. 2014, 2, 88-91. [CrossRef]

19. Herrero, M.; Thornton, P.K.; Notenbaert, A.M.; Wood, S.; Msangi, S.; Freeman, H.A.; Bossio, D.; Dixon, J.; Peters, M.; van de Steeg, J.; et al. Smart investments in sustainable food production: Revisiting mixed crop-livestock systems. Science 2010, 12, 822-825. [CrossRef] [PubMed]

20. Arias, P.; Hallam, D.; Krivonos, E.; Morrison, J. Smallholder Integration in Changing Food Markets; Food and Agriculture Organization of the United Nations: Rome, Italy, 2013.

21. Thornton, P.K.; Jones, P.G.; Owiyo, T.; Kruska, R.L.; Herrero, M.; Orindi, V.; Bhadwal, S.; Kristjanson, P.; Notenbaert, A.; Bekele, N.; et al. Climate change and poverty in Africa: Mapping hotspots of vulnerability. Afr. J. Agric. Resour. Econ. 2008, 2, 24-44.

22. Schlenker, W.; Lobell, D.B. Robust negative impacts of climate change. Environ. Res. Lett. 2010, 5, 014010. [CrossRef]

23. Khan, Z.R.; Pittchar, J.O.; Midega, C.A.; Pickett, J.A. Push-Pull Farming System Controls Fall Armyworm: Lessons from Africa. Outlooks Pest Manag. 2018, 29, 220-224. [CrossRef]

24. Kuwi, S.O.; Mutai, M.K.C.K.; Hanson, A.M.J.; Ghimire, A.D.S.R. Genetic diversity and population structure of Urochloa grass accessions from Tanzania using simple sequence repeat (SSR) markers. Braz. J. Bot. 2018, 41, 699-709. [CrossRef]

25. Cheruiyot, D.; Midega, C.A.O.; Van den Berg, J.; Pickett, J.A.; Khan, Z.R. Genotypic responses of brachiaria grass (Brachiaria spp.) accessions to drought stress. J. Agron. 2018, 17, 136-146. [CrossRef]

26. Cheruiyot, D.; Midega, C.A.O.; Ueckermann, E.A.; Van den Berg, J.; Pickett, J.A.; Khan, Z.R. Genotypic response of brachiaria (Urochloa spp.) to spider mite (Oligonychus trichardti) (Acari: Tetranychidae) and adaptability to different environments. Field Crop. Res. 2018, 225, 163-169. [CrossRef]

27. Cheruiyot, D.; Midega, C.A.O.; Van den Berg, J.; Pickett, J.A.; Khan, Z.R. Suitability of brachiaria grass as a trap crop for management of Chilo partellus. Entomol. Exp. Appl. 2018, 166, 139-148. [CrossRef]

28. Jaetzold, R.; Schmidt, H. Farm Management Handbook of Kenya: Natural Conditions and Farm Management Information; Ministry of Agriculture: Nairobi, Kenya, 1983; Volume II, Part B.

29. National Soil Service. Review of Fertilizer Recommendations in Tanzania. Part 2, Revised Fertilizer Recommendations for Tanzania; Mowo, J.G., Floor, J., Kaihura, F.B.S., Magoggo, J.P., Eds.; Ministry of Agriculture: Tanga, Tanzania, 1993.

30. Whitehead, A.; Tsikata, D. Policy discourses on women's land rights in Sub-Saharan Africa: The implications of the return to the Customary. J. Agr. Chang. 2003, 3, 67-112. [CrossRef]

31. Bezu, S.; Holden, S. Are rural youth in Ethiopia abandoning agriculture? World Dev. 2014, 64, $259-272$. [CrossRef]

32. Löwe, A.; Njambi-Szlapka, S.; Phiona, S. Youth Associations and Cooperatives: Getting Young People into Work; Youth Forward: Sacramento, CA, USA, 2019.

33. Djikeng, A.; Rao, I.M.; Njarui, D.; Mutimura, M.; Caradus, J.; Ghimire, S.R.; Johnson, L.; Cardoso, J.A.; Ahonsi, M.; Kelemu, S. Climate-smart Brachiaria grasses for improving livestock production in East Africa. Trop. Grassl. 2014, 2, 38-39. [CrossRef]

34. Gichangi, E.M.; Njarui, D.M.G.; Ghimire, S.R.; Gatheru, M.; Magiroi, K.W.N. Effects of cultivated Brachiaria grasses on soil aggregation and stability in the semi-arid tropics of Kenya. Trop. Subtrop. Agroecosystems 2016, 19, 205-217.

35. Ghimire, S.; Njarui, D.; Mutimura, M.; Cardoso, J.; Johnson, L.; Gichangi, E.; Teasdale, S.; Odokonyero, K.; Caradus, J.; Rao, I.; et al. Climate-smart Brachiaria for improving livestock production in East Africa: Emerging opportunities. In Proceedings of 23rd International Grassland Congress 2015-Keynote Lectures, New Delhi, India, 20-24 November 2015; Roy, M.M., Malaviya, D.R., Yadav, V.K., Singh, T., Sah, R.P., Vijay, D., Radhakrishna, A., Eds.; Range Management Society of India: Jhansi, India, 2015; pp. 361-370.

36. Fischer, G.; Shah, M.; Tubiello, F.N.; Van Velhuizen, H. Socio-economic and climate change impacts on agriculture: An integrated assessment, 1990-2080. Phil. Trans. Roy. Soc. Lond. B Biol. Sci. 2005, 360, 2067-2083. [CrossRef] 
37. The Royal Society. Reaping the Benefits: Science and the Sustainable Intensification of Global Agriculture; Royal Society: London, UK, 2009.

38. Tittonel, P.; Giller, K. When yield gaps are poverty traps: The paradigm of ecological intensification in African smallholder agriculture. Field Crop. Res. 2012, 143, 76-90. [CrossRef] 